\title{
Seleksi Berbagai Genotipe Jagung Manis, Cabai dan Kacang Panjang Hasil Pemuliaan IPB sebagai Penyedia Benih Unggul
}

\author{
Undang \\ Program Keahlian Teknologi Industri Benih - Program Diploma IPB
}

Diterima 09 April 2012/ Disetujui 30 September 2012

\begin{abstract}
Collection and selection are important steps in a breeding activity series. The purpose of this research is to produce new superior varieties of sweet corn, chilli and cowpea, as this research is also a bridge between researchers/lecturers (seed producer) and farmers (seed users). This research was conducted in Gunung Gede experimental garden, IPB Diploma Programs, commenced from August to December 2010. The genetic materials used are 1 (one) genotype of corn, 10 genotypes of cowpea, and 12 genotypes of chilli. The plant materials are strains produced by the Plant Breeding and Genetics Laboratory of Agronomy and Horticulture Department, IPB. The experiment was done in Randomized Block Complete Design, one factor is genotype. The negative and positive selection was applied on sweet corn selection, while the index selection was applied on chilli and cowpea. Selection on corn (with 20\% of selection proportion) produced 30 best plants. This step can be used as a startup to get the next population (with upturned genetics) to be better. The 5002046 is the best chilli genotype; meanwhile Cilibende, Kencana, K7 and Majalengka are the best cowpea genotypes. Selected chilli and cowpea genotypes are candidat lines for good seed production.
\end{abstract}

Keywords: corn, cowpea, chili, seed, selection.

\section{PENDAHULUAN}

Benih bermutu merupakan penentu potensi produktivitas suatu usaha tani, baik itu menyangkut komoditas tanaman pangan, hortikultura, perkebunan, kehutanan, ternak maupun ikan. Sekali pengusaha pertanian, besar atau kecil, menentukan pilihan penggunaan benih unggul bermutu pada awal proses produksinya, maka ketika itu pengusaha telah menentukan berapa besar hasil maksimum yang diharapkan dalam usaha taninya tersebut. Selain daripada itu dipahami pula bahwa $60 \%-65 \%$ peningkatan produktivitas suatu usaha tani ditentukan oleh faktor penggunaan benih unggul, terutama untuk komoditas tanaman.

Kesadaran terhadap manfaat penggunaan benih unggul bermutu, relatif tinggi di kalangan petani Indonesia. Benih hibrida tanaman seperti jagung, sayuran dan tanaman hias, ikan dan ternak yang relatif mahal, banyak dibeli dan dipergunakan petani. Tidak jarang jumlah yang diminati petani cukup besar.

Di lain pihak, kenyataan menunjukkan bahwa penyediaan benih unggul dalam negeri masih relatif sedikit, sebagian besar benih-benih unggul terutama sayuran dan beberapa buah-buahan masih impor. Seba-gai contoh, pada tahun 2000-2003 rata-rata ketersediaan benih unggul tanaman buah, sayur, tanaman hias dan obat berturut-turut baru bisa dipenuhi sebesar 5,95\%, 2,53\%, 2,0\% dan 1,5\% dari kebutuhan total (Dirjen Bina Produksi Tanaman Hortikultura, 2003).

Industri benih, khususnya industri benih hortikultura, cenderung meningkat. Sekalipun demikian industri perbenihan tanaman hortikultura masih pada taraf penangkar, sebagian besar benih varietas unggul bermutu diimpor, dan hanya sebagian kecil perusahaan benih dalam negeri yang membuat varietas unggul sendiri, terutama untuk varietas hibrida. Selain itu, globalisasi yang memungkinkan free movement of seed menyebabkan berbagai benih impor membanjiri Indonesia. Benih impor yang bermutu tinggi itu merupakan saingan berat bagi benih nasional. Sampai saat ini, kita masih terusik dengan asosiasi antara varietas unggul dengan Bangkok, karena itu sejarah pembangunan pertanian Thailand perlu menjadi perhatian. Pada tahun 1920, warga 
negara Thailand masuk perguruan tinggi di Amerika untuk belajar pertanian dan kesehatan masyarakat. Pada era 1940-an, ahli-ahli pertanian Amerika, terutama pemuliaan tanaman, dikirim ke Thailand. Pada tahun 1960-an, 6-10 orang dosen Thailand belajar IImu Pemuliaan. Tahun 1970-an, Thailand menerapkan pendekatan agribisnis dalam pembangunan pertanian. Orang Thailand mengatakan agriculture is not backbone, agriculture is our face.

Belajar dari Thailand tersebut di atas, maka program pemuliaan menjadi titik tumpu dalam pembangunan pertaniannya. Varietas unggul yang bermutu hanya bisa dihasilkan dari kegiatan pemuliaan tanaman. Bila varietas unggul tersedia maka industri benih dapat dibangun dan dikembangkan.

Program Diploma IPB, khususnya Program Studi Teknologi Industri Benih mempunyai potensi untuk mengembangkan industri benih tanaman melalui program pemuliaan tanaman. Dari segi sumberdaya lahan, dan sumberdaya manusia, Program Diploma dapat menunjang mengembangkan benih, sehingga benih hasil seleksi selalu berlanjut.

Tujuan penelitian ini adalah untuk menghasilkan karakter/genotipe unggul baru beberapa komoditas tanaman khususnya jagung manis, cabai dan kacang panjang, serta sebagai jembatan antara pemulia /dosen (produsen benih) dengan petani (pengguna benih).

\section{METODOLOGI}

Penelitian ini dilaksanakan pada bulan Agustus sampai dengan Desember 2010 bertempat di Kebun Percobaan Gunug Gede, Program Diploma IPB, meliputi lahan penanaman jagung, kacang panjang dan cabai. Bahan yang digunakan terdiri dari 1 (satu) genotipe jagung, 10 genotipe kacang panjang, dan 12 genotipe cabai hasil penelitian Bagian Genetika dan Pemuliaan Tanaman Departemen Agronomi dan Hortikul-tura IPB.

Penelitian ini akan melanjutkan pengembangan benih-benih jagung manis, kacang panjang dan cabai yang sudah digunakan dalam praktikum MK. Teknik Pemuliaan Tanaman. Benih awal merupakan hasil pemuliaan di bagian Genetika dan Pemuliaan Tanaman, Departemen Agronomi IPB. Benih jagung manis yang akan dilanjutkan merupakan hasil Seleksi Massa ke 3 dengan karakter benih berwarna oranye. Galur benih kacang panjang terdiri dari: Majalengka, Pilar, Malaysia, Cilibende, K7, Lorena, Kencana, Putih, Jombang merah dan Cibeurem (hasil seleksi dan persilangan mahasiswa TIB tahun 2005). Genotipe cabai yang digunakan merupakan turunan hasil persilangan antara cabai besar biasa, keriting, atau cabai besar berukuran kecil (mirip rawit) dan sebagai pembanding cabe komersil OPV (Open Polinated Variety) yaitu Trisula dan Gelora.

Penelitian disusun dalam Rancangan Acak Kelompok faktor tunggal dengan tiga ulangan (untuk masing-masing komoditi). Setiap satuan percobaan terdiri atas 20 tanaman untuk cabai dan kacang panjang dan 300 tanaman untuk jagung manis.

\section{Penanaman}

a. Jagung manis

Penanaman jagung manis (jarak tanam $75 \mathrm{~cm} \times 25 \mathrm{~cm}$ ) dilaksanakan di lahan yang juga merupakan lahan praktikum. Oleh karena itu di awal pelaksanaan akan diketahui terlebih dahulu jadwal praktikum terkait dengan komoditi yang akan ditanam sehingga dapat menentukan strategi barier waktu jika ternyata pada periode waktu yang sama melakukan penanaman jagung berbeda. Tujuannya supaya jagung dalam penelitian ini tidak mendapat kontaminasi polen dari jagung lain.

Pemupukan menggunakan pupuk organik (kotoran sapi) dengan dosis 10 ton/ha. Penanaman baru dilaksanakan pada 1 minggu setelah pemberian pupuk. Pada saat 
penanaman diberikan pupuk anorganik sebagai pupuk dasar terdiri atas urea $300 \mathrm{~kg} / \mathrm{ha}$, SP-36 $200 \mathrm{~kg} / \mathrm{ha}$ dan KCL $200 \mathrm{~kg} / \mathrm{ha}$. Urea diberikan secara bertahap dalam dosis sama yaitu pada saat tanam dan pada saat memasuki pembungaan. Pemberian furadan pada awal penanaman bertujuan untuk menghindari gangguan serangga tanah pemakan benih. Furadan juga diaplikasikan pada bagian pucuk saat tanaman berumur 3 MST untuk mengendalikan serangga penggerek batang. Penyulaman dilakukan hanya pada 1 MST untuk menghindari ketidakserempakan pertumbuhan.

b. Kacang panjang

Kacang panjang ditanam 2 benih per lubang dengan sistem tugal. Jarak tanam yang digunakan $50 \mathrm{~cm} \times 50 \mathrm{~cm}$. Penanaman dilakukan menggunakan mulsa PHP untuk menekan biaya pemeliharaan. Tanaman kacang panjang ini ditanam dalam sistem double row.

Pada awal penanaman diaplikasikan pupuk dasar yaitu urea, SP-36, dan KCL dalam alur serta diberi furadan. Penyulaman dilakukan sampai dengan 2 MST hanya pada lubang tanam yang kosong. Pengajiran dilaksanakan pada 2 MST dengan sistem ajir "A".

c. Cabai

Cabai merupakan jenis tanaman yang memerlukan penyemaian sebelum penanaman di lapang. Penyemaian benih pada tray mengguna-kan media campuran antara tanah dan pupuk kandang dengan perbandingan $1: 1$. Setiap lubang tray akan ditanami 1 benih cabai dan penyulaman hanya dilakukan pada 1 MST. Setiap minggu diberi pupuk kocor dengan dosis bertahap dan dilakukan pemeliharaan.

Transplanting dilaksanakan setelah bibit berumur 5 MST atau memiliki 8 daun utama. Transplanting dilaksanakan sore hari untuk mengurangi tingkat stress pada tanaman kecuali jika hari mendung. Untuk memacu pertumbuhan, maka diberikan starter solution dengan pupuk kocor pada saat tanam. Furadan diaplikasikan untuk mengendalikan serangga penggigit batang atau penggigit daun seperti belalang, jangkrik dan bekicot.

Setiap genotipe ditanam dalam bedeng berukuran $1 \mathrm{~m} \times 5 \mathrm{~m}$ secara double row. Jarak tanam adalah $50 \mathrm{~cm} \times 50 \mathrm{~cm}$. Pada awal tanam ini langsung dipasang ajir dan dilakukan pengikatan pertama untuk menghindari bersentuhannya batang atau daundaun muda dengan mulsa yang menyebabkan terbakar bahkan kematian tanaman.

\section{Pemeliharaan}

Pemeliharaan meliputi pengendalian gulma secara manual, pengendalian hama penyakit melalui penyemprotan menggunakan pestisida secara berkala dengan intensitas penyemprotan disesuaikan kondisi lapang, penyiraman dan pemupukan. Pemupukan tanaman cabai dan kacang panjang dilakukan secara rutin setiap minggu dengan aplikasi kocor. Pupuk kocor merupakan larutan yang terdiri atas $10 \mathrm{~g} / \mathrm{L}$ air NPK mutiara, 1-2 g/L air gandasil D, 1-2 g/L air antracol atau dithane M-45.

Setiap minggu dilakukan perambatan sulur-sulur kacang panjang yang keluar bedeng. Pewiwilan pada cabai dilaksanakan setiap minggu selama fase vegetatif pada bagian batang utama. Pengikatan cabai dengan tali rafia juga dilaksanakan dalam 3 tahap yaitu awal tanam, saat terbentuk dikotomous dan pembungaan.

Data yang dan diolah merupakan data primer hasil pengamatan dilapangan, dari masing-masing komoditi yang diamati pada fase vegetatif maupun generatif. Penelitian ini merupakan tahapan awal dan lanjutan dari suatu tahapan pemuliaan yang sudah dilakukan.

a. Jagung

Komoditi jagung merupakan kegiatan lanjutan dari tahap seleksi massa yang telah dilaksanakan sebanyak 3 musim. Pada setiap musim dilaksanakan seleksi dalam 2 
fase yaitu vegetatif dan generatif. Pada fase vegetatif diterapkan seleksi negatif dengan cara membuang individu-individu yang pertumbuhannya terhambat atau sakit dan hanya menyisakan tanaman yang vigour dan sehat per lubang tanam. Seleksi ini dilaksanakan pada 3 MST. Seleksi kedua, seleksi positif yaitu menandai tanaman-tanaman yang memiliki pertumbuhan baik, sehat dan tidak rebah. Penandaan dilakukan dengan memberikan cincin raffia pada pangkal batang jagung. Waktu seleksi ini adalah sebelum munculnya bunga jantan. Individu-individu yang tidak lolos seleksi harus didetaselling untuk menghilangkan sumbangan gen-gen tidak diharapkan melalui polennya dan benihnya tidak diambil sebagai benih. Seleksi ketiga adalah terhadap tongkol yang dihasilkan. Intensitas seleksi (i) dalam penelitian ini adalah $20 \%$.

Karakter pengamatan meliputi: tinggi tanaman, diameter batang, tinggi tongkol, jumlah tongkol per tanaman, bobot tongkol dengan kelobot, bobot tongkol tanpa kelobot, panjang tongkol, jumlah daun, panjang baris biji, bobot 100 biji, jumlah biji per tongkol, diameter tongkol dan bobot biji pipil.

b. Kacang panjang

Kegiatan penelitian ini, yaitu melakukan seleksi kacang panjang yang memiliki produksi tinggi, ditunjang dengan komponen hasil yang positif. Pengamatan difokuskan pada: jumlah polong, bobot polong total per tanaman, bobot per polong, yaitu bobot ratarata 20 polong contoh, panjang polong, yaitu panjang 20 polong contoh, diameter polong dan jumlah biji per polong (buah).

c. Cabai

Cabai yang digunakan adalah turunan hasil persilangan untuk menghasilkan galur-galur unggul. Idiotype tanaman akan sangat menentukan dalam proses seleksi selain juga informasi akurat dari data hasil pengamatan di lapang. Sehingga dalam penentuannya nanti akan merupakan gabungan dari kedua informasi tersebut.

Pengamatan dilapang dilakukan terhadap : diameter batang, tinggi tanaman, hari berbunga, diamati terhadap setiap individu, lebar kanopi, bobot total tanaman, bobot per buah, rata-rata 10 buah contoh per tanaman, panjang buah, diameter buah dan karakter kualitatif (warna mahkota, warna buah) serta tekstur buah dan bentuk buah.

\section{Analisis data}

Penelitian ini merupakan kegiatan seleksi jagung, kacang panjang dan cabai dengan beberapa pertimbangan karakter secara bersamaan atau simultan. Seleksi indeks terboboti dilakukan dalam menentukan genotipe cabai dan kacang panjang terbaik berdasarkan karakter yang diamati. Indeks seleksi terboboti dilakukan dengan menggunakan persamaan menurut Falconer (1967).

Keterangan:

$$
I=a_{1} Z_{1}+a_{2} Z_{2}+a_{3} Z_{3}+\ldots .+a_{n} Z_{n}
$$

I $=$ Indeks seleksi terboboti

$\mathrm{an}_{\mathrm{n}} \quad=$ Bobot dari peubah

$\mathrm{Zn}_{\mathrm{n}} \quad=\quad$ Nilai fenotipe tiap genotipe yang telah distandarisasi untuk peubah ke-n berdasarkan rumus:

$$
\mathrm{Z}_{\mathrm{n}}=\frac{\mathrm{x}-\overline{\mathrm{z}}}{\sqrt{\bar{\sigma}^{2} \text { gallat }}}
$$

$\mathrm{X}=$ Nilai tengah peubah tiap genotipe

$\bar{x} \quad=\quad$ Nilai tengah peubah

$\sigma_{\text {galat }}^{2}=$ Ragam galat 
Metode seleksi massa diterapkan dalam melakukan seleksi populasi jagung manis untuk memperbaiki keragaan populasi turunan sehingga dapat menduga kemajuan genetik dari setiap generasi.

\section{HASIL DAN PEMBAHASAN}

\section{Seleksi Tanaman Jagung}

Jagung merupakan tanaman yang secara alami bersifat menyerbuk silang (open pollinated), sehingga genotipe dari setiap individu diasumsikan bersifat heterogen heterozigot. Setiap individu tanaman mewakili genotipe yang berbeda. Penampilan tanaman jagung dapat dilihat pada Gambar 1. Seleksi massa negatif dengan proporsi seleksi sebesar $20 \%(I=1.38 \%)$ dilakukan ketika tanaman masih berada dalam fase vegetatif. Kegiatan tersebut bertujuan untuk mereduksi efek tidak menguntungkan dari individu yang dianggap berpenampilan negatif, yaitu ukuran panjang tanaman yang ekstrim, rebah, offtype atau terkena hama penyakit.

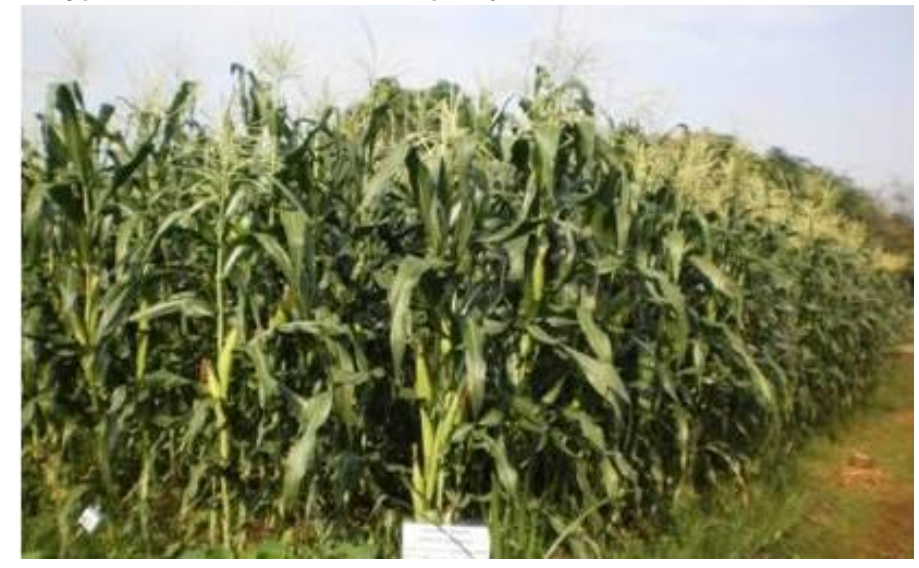

Gambar 1. Penampilan tanaman jagung manis pada saat sudah berbunga.

Seleksi massa positif dilakukan dengan menandai individu tanaman jagung yang berpenampilan superior, tidak rebah dan tidak terkena hama penyakit. Data karakter kuantitatif jagung hasil seleksi disampaikan dalam Tabel 1.

Tabel 1. Karakter Kuantitatif Tanaman Jagung Hasil Seleksi Massa

\begin{tabular}{lr}
\hline Karakter & Nilai Tengah \\
\hline Tinggi tanaman & 282.744 \\
Diameter batang & 20.567 \\
Tinggi tongkol & 128.889 \\
Jumlah tongkol & 1.000 \\
Bobot tongkol + kelobot & 150.478 \\
Bobot tongkol tanpa kelobot & 124.994 \\
Panjang tongkol & 17.821 \\
Jumlah daun & 11.000 \\
Panjang baris biji & 16.722 \\
Bobot 100 biji & 15.933 \\
Jumlah bij/tongkol & 526.000 \\
Diameter tongkol & 43.603 \\
Bobot biji & 80.378 \\
\hline
\end{tabular}


Tanaman yang tidak terpilih di- detasseling ketika telah muncul tassel atau bunga jantan. Detasseling bertujuan untuk menghilangkan sumbangan gen tidak menguntungkan dari individu tanaman yang tidak terseleksi. Biji dari tanaman ini tidak digunakan sebagai benih.

Seleksi positif dilakukan terhadap tongkol jagung dengan intensitas seleksi $20 \%$ $(\mathrm{i}=1.38 \%$ ). Kriteria seleksi tongkol jagung adalah ukuran yang proporsional antara panjang tongkol, diameter tongkol, kerapatan biji dalam baris dan kesehatan tongkol. Penampilan tongkol jagung yang terpilih dan tidak terpilih dapat dilihat pada Gambar 2.

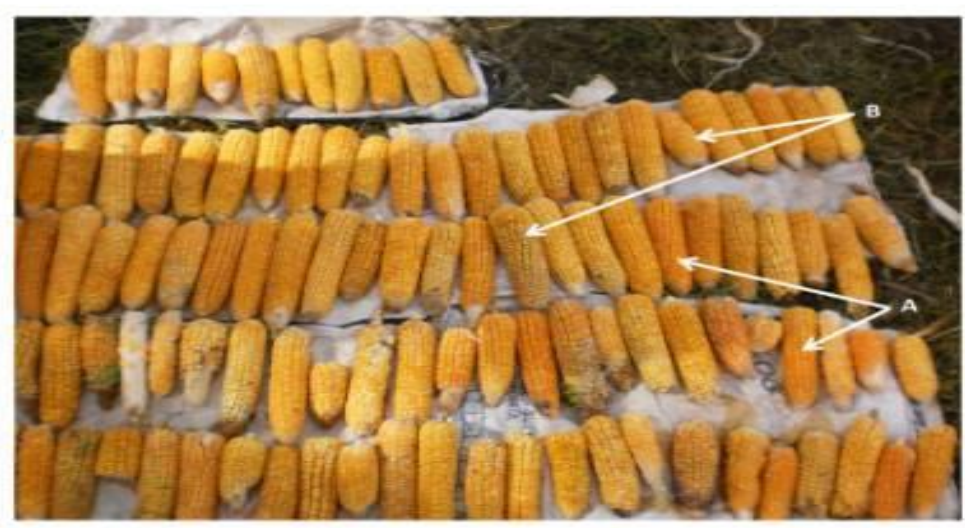

Gambar 2. Keragaan Tongkol Jagung Kering pada saat Panen.

A. Contoh Tongkol Terseleksi.

B. Contoh Tongkol tidak Terseleksi

Benih jagung hasil seleksi dipipil dan di-bulk, untuk digunakan lagi pada musim tanam berikutnya. Seleksi pada musim tanam selanjutnya diduga akan memberikan keragaan jagung yang lebih baik. Kemajuan genetik $(G)$ diduga akan diperoleh sebesar $\mathrm{X}_{\mathrm{f}(\mathrm{n}-1)}-\mathrm{X}_{\mathrm{fn}}$, yaitu selisih nilai tengah populasi hasil seleksi dengan populasi awal atau dapat diduga dengan menggunakan rumus $G=(i)\left(\sigma_{P}\right)\left(h^{2}\right)$, dimana i adalah intensitas seleksi yaitu 1.38\%; $\sigma_{p}$ adalah standar deviasi fenotipe dan $\mathrm{h}^{2}$ adalah heritabilitas arti luas. Akan tetapi pada populasi ini belum dapat dihitung besarnya kemajuan genetik karena tidak ada data kuantitatif pada populasi sebelumnya. Seleksi akan menciptakan pergeseran nilai kearah kanan dari suatu sebaran populasi yaitu kearah nilai yang lebih baik karena adanya pemilihan individu-individu terbaik.

\section{Seleksi Tanaman Kacang Panjang}

Seleksi secara tidak langsung atau simultan untuk meningkatkan daya hasil berdasarkan indeks seleksi akan lebih efisien dibandingkan dengan seleksi berdasarkan satu karakter atau kombinasi dari dua karakter saja (Soh et al., 1994; Moeljopawiro, 2002). Seleksi beberapa karakter tepat dilakukan untuk karakter yang sangat dipengaruhi lingkungan seperti produksi, terekspresi dengan lambat atau memiliki nilai heritabilitas rendah (Biswass et al., 2001; Wirnas, 2006).

Genotipe terbaik dari genotipe-genotipe yang diuji berdasarkan beberapa karakter yang diamati dilakukan melalui seleksi berdasarkan indeks terboboti (Falconer, 1976). Pembobot tertinggi pada penelitian ini ditetapkan terhadap karakter bobot polong per tanaman, diikuti oleh bobot per polong. Nilai pembobot sama diberikan terhadap karakter jumlah polong, panjang polong dan jumlah biji per polong, sedangkan pembobot terendah sebesar 1 untuk diameter buah. Tujuan pembobotan demikian adalah untuk mendapatkan genotipe kacang panjang dengan potensi produksi tinggi, memiliki ukuran 
polong yang proporsional dengan diameter yang tidak terlalu besar dan potensi produksi benih yang tinggi.

$$
I=2 Z_{1}+4 Z_{2}+6 Z_{3}+2 Z_{4}+Z_{5}+2 Z_{6}
$$

Keterangan:

$Z_{1}=$ jumlah polong

$Z_{2}=$ bobot per polong

$$
\mathrm{Z}_{4}=\text { panjang polong }
$$

$Z_{3}=$ bobot polong per tanaman $Z_{6}=$ jumlah biji per polong

Nilai indeks seleksi setiap genotipe yang diuji dapat dilihat pada Tabel 2. Genotipe kacang panjang yang diuji umumnya memiliki nilai indeks terboboti lebih tinggi dari varietas pembanding Lorena. Genotipe Malaysia merupakan genotipe dengan indeks terboboti paling rendah diantara semua genotipe yang diuji maupun dengan kedua varietas pembandingnya. Genotipe Cilibende, Kencana, K7 dan Majalengka memiliki nilai indeks terboboti yang lebih tinggi dari Pilar dan Lorena. Penampilan kelima genotipe dapat dilihat pada Gambar 3.

\section{Seleksi Galur Cabai}

Seleksi indeks terboboti merupakan teknik seleksi dalam menentukan genotipe cabai terbaik dari genotipe-genotipe yang diuji berdasarkan beberapa karakter. Karakter yang digunakan dalam seleksi ini distandarisasi untuk meniadakan perbedaan yang disebabkan oleh skala variabel dan jenis unit dari variabel yang berbeda. Penentuan besarnya nilai pembobot dilakukan berdasarkan urutan kepentingan dari karakterkarakter yang digunakan. Penentuan pembobot ditentukan sesuai dengan tingkat kepentingan karakter menurut pemulia.

Tabel 2. Indeks Seleksi Terboboti beberapa Genotipe Kacang Panjang

\begin{tabular}{lccccccc}
\hline \multicolumn{1}{c}{ Genotipe } & Z1 & Z2 & Z3 & Z4 & Z5 & Z6 & I \\
\hline Cilibende & 5.468 & 39.517 & 220.306 & 37.955 & 5.321 & 4.858 & $\mathbf{1 5 6 5 . 8 2 2}$ \\
Kencana & 5.401 & 40.003 & 219.500 & 37.320 & 5.287 & 5.162 & $\mathbf{1 5 6 2 . 2 0 0}$ \\
K7 & 4.999 & 39.338 & 218.457 & 36.706 & 4.810 & 4.892 & $\mathbf{1 5 5 1 . 6 6 6}$ \\
Majalengka & 7.209 & 39.948 & 215.992 & 35.897 & 3.863 & 7.254 & $\mathbf{1 5 4 8 . 7 3 7}$ \\
Putih & 7.008 & 37.982 & 215.802 & 37.450 & 4.015 & 7.052 & 1541.733 \\
Jombang & & & & & & & \\
Merah & 6.807 & 38.059 & 215.897 & 35.948 & 3.880 & 6.883 & 1539.135 \\
Cibeureum & 7.008 & 36.090 & 212.626 & 32.373 & 3.260 & 6.849 & 1506.057 \\
Malaysia & 6.004 & 35.860 & 23.896 & 11.221 & 2.450 & 6.072 & 328.509 \\
\hline Pilar & 7.008 & 39.696 & 216.181 & 35.529 & 4.162 & 6.883 & 1546.388 \\
Lorena & 4.798 & 36.474 & 212.816 & 30.158 & 4.152 & 4.554 & 1493.506 \\
\hline
\end{tabular}

Anggraini (2006) menetapkan karakter bobot buah per tanaman sebagai karakter utama dengan memberikan pembobot sebesar 5; jumlah buku pertanaman dan jumlah buah per tanaman dengan pembobot 4; bobot buah, panjang buah dan diameter buah dengan pembobot 2; tinggi tanaman dan tinggi dikotomous memiliki pembobot (-1); serta umur berbunga dan umur mulai panen memiliki pembobot (-2). Sujiprihati (2007) memberikan pembobot 1 untuk karakter ukuran buah yaitu panjang, diameter dan bobot buah, sedangkan karakter produktivitas per tanaman diberi pembobot sebesar 3 . 


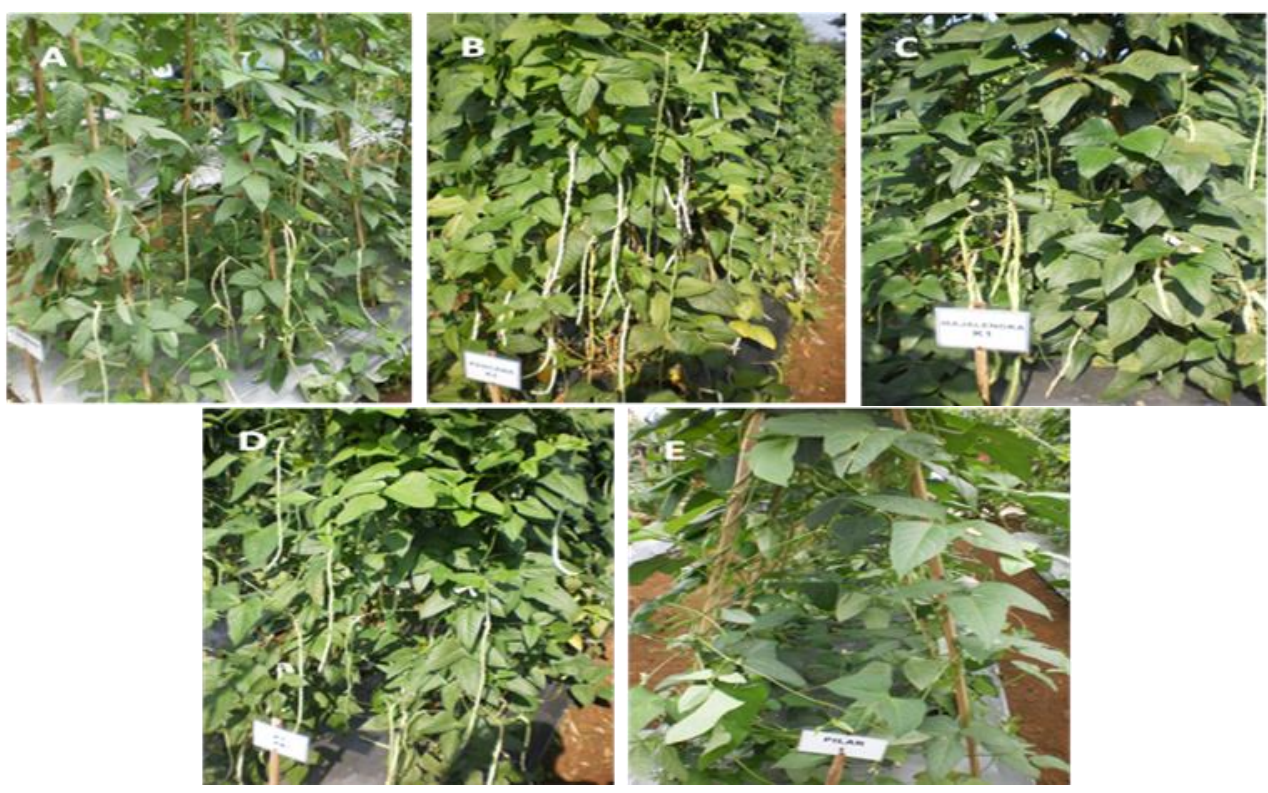

Gambar 3. Keragaan Genotipe Kacang Panjang. A. Cilibende, B. Kencana, C. K7, D. Majalengka, dan E. Pilar.

Karakter bobot buah per tanaman pada penelitian ini memiliki pembobot terbesar sebagai karakter utama, kemudian karakter ukuran buah yaitu bobot, panjang dan diameter per buah sebagai karakter yang menentukan bobot per tanaman. Karakter diameter batang diboboti dengan nilai +1 karena batang yang kokoh akan berpengaruh baik terhadap pertumbuhan dan perkembangan tanaman. Karakter tinggi tanaman, hari berbunga dan hari pertama panen diboboti dengan (-1) karena tujuan seleksi lebih mengarah untuk mendapatkan genotipe cabai dengan habitus tidak terlalu tinggi dan bersifat genjah. Model indeks terboboti yang digunakan yaitu :

Keterangan:

$$
I=Z_{1}-Z_{2}-Z_{3}+Z_{4}+6 Z_{5}+4 Z_{6}+4 Z_{7}+4 Z_{8}
$$

$Z_{1}=$ diameter batang

$Z_{5}=$ bobot buah per tanaman

$\mathrm{Z}_{2}=$ tinggi tanaman

$Z_{6}=$ bobot buah

$\mathrm{Z}_{3}=$ hari berbunga

$\mathrm{Z}_{7}=$ panjang buah

$\mathrm{Z}_{4}=$ lebar kanopi

$\mathrm{Z}_{8}=$ diameter buah

Seleksi cabai berdasarkan indeks terboboti menunjukkan urutan genotipe yang diuji dari urutan tertinggi sampai terendah seperti terlihat pada Tabel 3 . Genotipe 6019015 dan genotipe 5002046 memiliki nilai indeks seleksi terboboti yang lebih tinggi dibandingkan delapan galur lainnya dan lebih tinggi daripada kedua pembanding, sehingga terpilih sebagai genotipe terbaik. Genotipe 5002046 memiliki idiotype buah yang lebih menarik dibandingkan dengan 6019015 yaitu memiliki ukuran yang lebih panjang, proporsional, tekstur buah yang licin dan warna merah tua saat matang. Ciri-ciri demikian terdapat pada buah dari varietas komersil cabai besar pada umumnya. 
Tabel 3. Urutan Genotipe Cabai berdasarkan Indeks Seleksi Terboboti

\begin{tabular}{lrrrrrrrrr}
\hline Genotipe & Z1 & Z2 & Z3 & Z4 & Z5 & Z6 & Z7 & Z8 & I \\
\hline 6019015 & $-0,173$ & 0,174 & 0,589 & $-1,027$ & $-0,575$ & 0,046 & 0.421 & $-1,335$ & $\mathbf{3 8 , 2 0 5}$ \\
5002046 & 0,105 & 2,371 & $-0,389$ & 1,918 & $-1,036$ & 3,083 & 2.285 & 0,755 & $\mathbf{1 8 , 3 1 8}$ \\
6009002 & $-2,319$ & $-2,965$ & $-0,715$ & $-1,627$ & 0,825 & $-1,831$ & -0.099 & $-3,013$ & 5,874 \\
6004005 & $-1,201$ & $-1,899$ & $-0,715$ & $-1,055$ & $-0,628$ & 0,043 & -0.703 & $-0,58$ & 0,171 \\
6009015 & $-0,16$ & $-0,628$ & 0,806 & $-1,028$ & 0,449 & $-0,109$ & -0.577 & 0,398 & $-0,534$ \\
6002001 & $-0,656$ & $-0,291$ & 0,589 & 0,96 & 0,22 & 0,794 & 1.653 & $-1,31$ & $-8,37$ \\
5001004 & 0,474 & 3,804 & $-0,172$ & $-0,045$ & 0,827 & $-0,591$ & -1.481 & 1,499 & $-8,879$ \\
5015002 & $-0,456$ & 1,48 & $-0,389$ & $-0,004$ & $-1,023$ & $-0,803$ & -0.316 & $-2,052$ & $-15,084$ \\
6015008 & 0,68 & 2,292 & 0,371 & 1,009 & $-0,314$ & $-1,51$ & -1.961 & 0,244 & $-15,765$ \\
6009019 & 2,045 & $-0,022$ & 1,132 & 2,224 & 2,342 & 0,71 & 0.338 & 4,2 & $-20,375$ \\
\hline Gelora & 1,497 & $-1,265$ & $-0,715$ & $-0,916$ & $-1,191$ & $-0,237$ & 0.314 & $-0,519$ & $-6,353$ \\
Trisula & 0,162 & $-3,051$ & $-0,389$ & $-0,408$ & 0,103 & 0,405 & 0,128 & 1,712 & 12,791 \\
\hline
\end{tabular}

Cabai merupakan tanaman hortikultura dalam kelompok sayuran buah. Oleh karena itu, perhatian terhadap kualitas dan kuantitas buah menduduki peringkat utama. Dengan demikian, seleksi pada cabai akan sangat bermanfaat jika dilakukan dengan mempertimbangkan idiotype tanaman yang sesuai dengan preferensi konsumen. Berdasarkan hasil nilai indeks seleksi terboboti (I) dan juga idiotype tanaman maka genotipe 5002046 merupakan kandidat genotipe cabai besar yang terpilih untuk dikembangkan lebih lanjut. Penampilan tanaman dan buah cabai dapat dilihat pada Gambar 4.

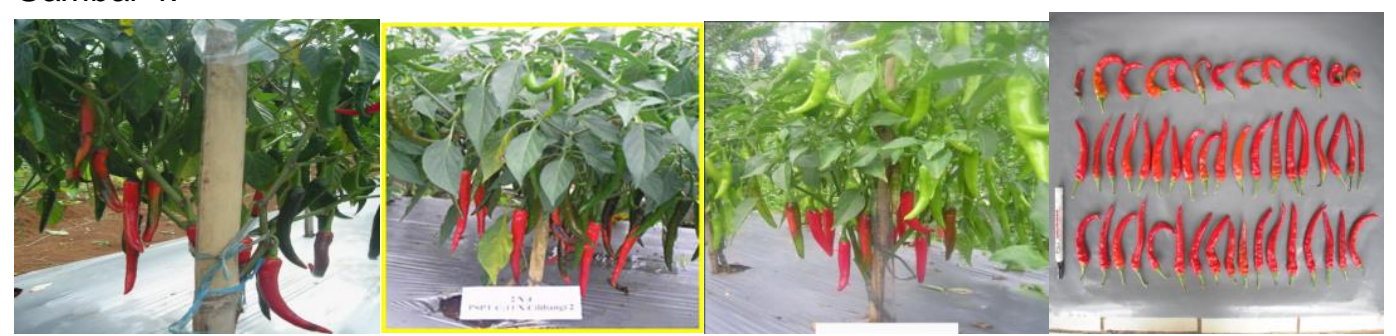

Gambar 4. Tanaman dan Buah Cabai

\section{Simpulan}

\section{SIMPULAN DAN SARAN}

Gabungan seleksi massa negatif dan positif pada jagung dapat mengurangi pengaruh individu yang tidak diinginkan pada generasi berikutnya. Berdasarkan hasil seleksi indeks terboboti pada tanaman cabai diperoleh genotipe terbaik yaitu F6-019015 dan F5-002046, sedangkan pada kacang panjang diperoleh genotipe Cilibende, Kencana, K7 dan Majalengka. Genotipe-genotipe jagung, kacang panjang dan cabai terpilih dapat dijadikan sebagai bahan untuk memproduksi benih selanjutnya.

\section{Saran}

Penelitian lebih lanjut diperlukan untuk mengetahui kemajuan genetik jagung yang dicapai pada generasi lebih lanjut, sehingga benih yang dihasilkan berasal dari populasi yang telah memiliki kemajuan genetik yang unggul. Pengujian potensi hasil dan sejauhmana pewarisan sifat tetua menurun pada generasi berikutnya perlu dilakukan pada genotipe cabai dan kacang panjang untuk mendapatkan benih yang bermutu. 
DAFTAR PUSTAKA

Anggraini, P. 2006. Keragaan Sembilan Genotipe Cabai Merah (Capsicum annuum L.) Generasi Keempat Hasil Persilangan Three Way Cross [Skripsi]. Fakultas Pertanian, Institut Pertanian Bogor. 34 Hal.

Baihaki, A. 2000. Teknik Rancang dan Analisis Penelitian Pemuliaan. Diktat kuliah. Fakultas Pertanian, Universitas Padjadjaran. Bandung. 19 Hal.

Biswass, B. K., M. Hasanuzzaman, F. El Taj, M.S. Alam, M.R. Amin. 2001. Simultaneous selection for fodder and grain yields in Sorghum. Journal of Biological Sciences 1 (5): 321-323.

Direktorat Jendral Bina Produksi Hortikultura. 2003. Luas Panen, Produksi dan produktivitas sayuran di Indonesia tahun 1999-2002. http://www.hortikultura.go.id/horti/page/statistik/Lppsayuran.asp.[21Mei 2005].

Falconer, D. S. 1976. An Introduction to Quantitative Genetics. Longman Group, Ltd. London. 365p.

Moeljopawiro, S. 2002. Optimizing selection for yield using selection index. Zuriat. 13 (1): 35-43.

Poepodarsono, S. 1988. Dasar-dasar IImu Pemuliaan Tanaman. PAU IPB. Bogor. 169 hal.

Sujiprihati, S., M. Syukur dan R. Yunianti. 2007. Pengujian Cabai Hibrida IPB di Dua Lokasi. Prosiding Seminar Nasional Hasil Penelitian yang dibiayai oleh Hibah Kompetitif. Peningkatan Perolehan HKI dari Hasil Penelitian yang dibiayai oleh Hibah Kompetitif. Bogor, 1-2 Agustus 2007.

Wirnas D., I. Widodo, Sobir, Trikoesoemaningtyas, D. Sopandie. 2006. Pemilihan Karakter Agronomi untuk Menyusun Indeks Seleksi pada 11 Populasi Kedelai Generasi F6. Bul. Agron. (34) (1) $19-24$. 